\title{
ASSOCIATION BETWEEN WORK POSTURE AND MUSCULOSKELETAL COMPLAINT AMONG TRADITIONAL GOLD MINERS, WEST LOMBOK, WEST NUSA TENGGARA
}

\author{
Metta Octora'), NK Wilmayani'), Ardiana Ekawanti3), \\ Ni Komang Ayu Swanitri Wangiyana4)
}

\author{
1)Department of Public Health, Faculty of Medicine, Universitas Mataram \\ 2)Department of Biochemistry, Faculty of Medicine, Universitas Mataram \\ 3)Faculty of Medicine, Universitas Mataram
}

\begin{abstract}
Background: The prevalence of musculoskeletal disorders (MSD) in various professions has been well established. It can have detrimental effects on the industry, including lower productivity and early retirement. Little is known about the detrimental effects of non ergonomic work posture among the traditional gold miners in West Lombok, West Nusa Tenggara. This study aimed to examine association between work posture and musculoskeletal complaint among traditional gold miners in Sekotong, West Lombok, West Nusa Tenggara.

Subjects and Method: This was a cross sectional study conducted at a small traditional gold mining in Pelangan Village, Sekotong Sub-District, West Lombok District, West Nusa Tenggara, from August to September 2015. A sample of 53 gold miners was selected for this study by random sampling. The dependent variable was musculoskeletal complaint. The independent variable was work posture. The musculoskeletal complaint was measured by Standardized Nordic Questionnaire. The work posture was measured by Rapid Entire Body Assessment (REBA). The association between variables was measured by contingency coefficient.

Results: Of all 53 gold miners under study, 31 (58.5\%) had moderately non ergonomic work posture, 16 (30.2\%) had highly non ergonomic work posture, 6 (11.3\%) had very highly non ergonomic work posture. As many as 38 (71.7\%) gold miners had musculoskeletal complaint. Non ergonomic work posture was positively correlated with musculoskeletal complaint on the shoulder $(r=0.37 ; p=$ $0.014)$, back $(\mathrm{r}=0.37 ; \mathrm{p}=0.014)$, and waist $(\mathrm{r}=0.33 ; \mathrm{p}=0.039)$.

Conclusion: Musculoskeletal complaint is associated with non ergonomic work posture among the traditional gold miners in Sekotong, West Lombok, West Nusa Tenggara.
\end{abstract}

Keywords: work posture, musculoskeletal complaint, Standardized Nordic Questionnaire, Rapid Entire Body Assessment

\section{Correspondence:}

Metta Octora. Department of Public Health, Faculty of Medicine, Mataram University, Mataram, West Nusa Tenggara.Email:momokoimut@gmail.com 